\title{
房屋建筑施工管理中存在的问题及对策
}

\section{Problems and Countermeasures in Building Construction Management}

\section{张建华}

Jianhua Zhang

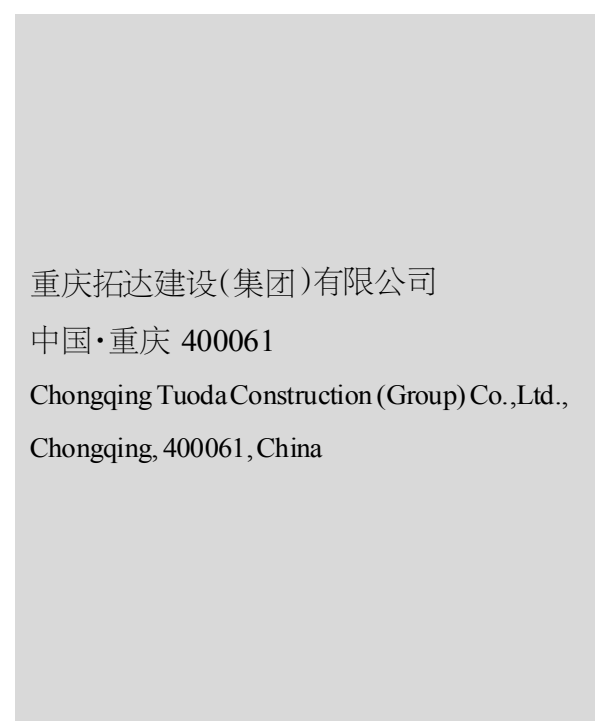

【摘要】在现代化社会的发展中,建筑行业建设规模在不断扩大,市场竞争日益激烈, 企 业需要做好施工管理工作。在房屋建筑施工管理过程中, 相关管理部门需要在传统的房屋 建筑施工管理模式中, 明确其中存在的问题, 并采取针对性的优化措施, 为房屋建筑施工 的有序开展提供支持。

【Abstract】In the development of modern society,the construction industry construction scale is expanding,the market competition is increasingly fierce,enterprises need to do a good job in construction management.In the process of building construction management,relevant management departments need to clarify the existing problems in the traditional building construction management mode, and take targeted optimization measures to provide support for the orderly development of building construction.

【关键词】房屋建筑; 施工管理; 问题;对策

【Keywords】building construction; construction management; problem; countermeasure 【DOI】10.36012/etr.v1i3.381

\section{1 引言}

在城市化建设日益推进的大背景下，中国房屋建筑工程 数量日益增加,在一定程度上推动着社会经济的发展。施工管 理是房屋建筑施工的关键, 不仅关系着房屋建筑的整体质量, 还直接影响着房屋建筑工程建设的有效实施[1。因此,施工企 业需要重视房屋建筑工程施工管理工作, 为提升房屋建筑工 程的整体质量提供保障。基于此,文章阐述了房屋建筑施工管 理的作用, 分析了房屋建筑施工管理的现状, 并对房屋建筑施 工管理的对策进行了研究。

\section{2 房屋建筑施工管理的作用}

在房屋建筑工程项目建设过程中，施工管理是其中的关 键内容, 发挥着十分重要的作用, 具体体现在以下方面: 第一, 房屋建筑施工管理工作的有效实施能够提升工程项目的施工 质量，尤其是施工过程中的质量管理工作与房屋建筑工程质 量息息相关。房屋建筑工程施工极易受到各种不利因素的影 响,如施工流程、检测方法、施工设计方案、施工组织等, 在很 大程度上影响着房屋建筑工程的整体质量。因此, 在房屋建筑 工程建设中, 施工企业需要做好施工管理工作, 有效地提升工 程项目的施工质量。第二,施工管理工作会对施工企业的综合 效益带来影响。在现代化市场经济环境的发展中,建筑行业之
间的竞争日益激烈,施工企业为了获取更多的效益,应该加强 施工管理力度, 将其作为房屋建筑工程管理的重点内容, 尤其 要加强施工成本和施工进度管理。因此,施工企业在施工现场 管理过程中,应该关注施工的各个环节,在确保施工质量的基 础上,减少施工成本, 为企业创造更多效益。第三,施工管理会 对工程管理水平带来一定的影响。在房屋建筑管理过程中,管 理水平主要体现在施工单位整体管理中, 管理部门需要实行 有效、合理的管理措施, 这样既能够降低工程建设的成本, 又 能够避免施工质量问题, 为企业创造更多效益。除此之外, 科 学、合理的房屋建筑施工管理方式能够确保工程项目建设的 有效实施, 提升房屋建筑工程的整体质量, 有助于施工成本控 制工作的顺利开展。

\section{3 房屋建筑施工管理存在的问题}

在社会经济的快速发展中，很多先进技术已融入房屋建 筑施工管理过程中, 在很大程度上推动着房屋建筑施工管理 工作的有效实施。然而,实际施工管理过程中仍存在一系列问 题,下文主要对施工管理问题进行了分析。

\section{1 管理资金投入不足}

通常情况下, 房屋建筑施工持续时间比较长, 涉及内容较 多, 而施工资金普遍是根据施工进度给付, 这就使得房屋建筑 
土木建筑工程 Civil and Architectural Engineering

工程处于欠款施工的状态，尤其是国家针对农民工工资拖欠 问题出台了相应的管理处罚政策，为施工企业带来了很大压 力。因此,在实际施工管理过程中,相关部门往往会将资金投 入到农民工工资和施工材料中，而出现施工管理资金不足的 问题，导致施工企业在施工管理中投入的资金受到了很大影 响, 无法实现施工管理工作的有效实施。另外,施工企业管理 部门的职责不够明确, 未将具体责任落实到个人,引发了一系 列管理问题。

\section{2 建筑施工材料管理有待加强}

房屋建筑工程施工环节比较多, 持续时间长, 这就使得房 屋建筑质量和使用价值的影响因素比较多。建筑施工原材料 是其中的主要影响因素之一, 主要作用于建筑物构成, 这就使 得建筑物质量与施工原材料联系十分密切 ${ }^{[2]}$ 。现阶段, 新型建 筑模式日益增加,在一定程度上推动着建筑原材料的发展, 使 得建筑原材料的分类不断增加。相关人员在选择建筑原材料 过程中, 极易遇到质量不过关的建筑原材料, 而这些材料一旦 投人施工现场就会出现一系列质量问题, 不仅会影响施工工 期, 还会增加施工难度, 影响房屋建筑的整体质量。

\section{3 施工安全管理不到位}

施工安全问题是施工管理中的关键,安全帽、防火防爆等 都是工程项目建设中的安全问题, 贯穿于施工的全过程, 施工 管理人员必须要予以重视，这样才能够确保房屋建筑施工管 理工作的有效实施。在房屋建筑实际施工过程中,存在一系列 安全隐患, 如施工人员未佩戴安全用具, 随意进出施工现场, 夏季穿拖鞋进人施工现场, 高空作业过程中未佩戴安全帽, 施 工现场安全标志不全, 危险物品、易燃易爆物品未进行单独存 放等,一旦出现这些问题,将会带来一系列的生命财产损失。

\section{4 房屋建筑施工管理的对策}

\section{1 做好施工安全管理工作}

在房屋建筑施工管理过程中, 施工企业需要建设安全的 施工现场, 并做好监督和管理工作, 施工人员应该听从指挥人 员的安排,严禁出现独自开工和停工的现象; 企业还要开展安 全教育培训活动, 严格防护施工现场的安全事故, 在施工过程 中设置安全标志, 严禁非工作人员进人施工现场, 避免引发安 全事故。同时,在实际施工过程中, 施工人员需要严格按照相 关要求进行施工, 确保施工质量满足相关要求。监督管理人员 还需要按照相关要求采购和分发防护用具, 进入施工现场的 工作人员必须严格佩戴防护用具, 减少人员伤亡问题。除此之 外, 施工企业在遇到高危作业时, 需要根据工程项目的实际情 况制定安全防护措施, 并将其落实到实际作业过程中, 安排专
业人员做好检查和监督工作, 减少安全事故的发生。

\section{2 重视施工材料管理}

在房屋建筑施工管理过程中, 为了有效地提升施工管理 效率,施工企业应该做好施工材料管理工作。首先,在施工准 备阶段,施工企业应该全面了解建筑物的使用要求, 确保房屋 建筑设计和施工满足相关要求, 以便合理地选择施工材料。其 次,在选择施工材料的过程中,施工企业需要严格按照相关原 则, 确保施工材料的质量满足要求, 避免后期施工过程中出现 质量问题。最后, 在对施工材料进行管理的过程中, 施工企业 应该确保施工原材料质量满足相关要求, 有效节省施工材料 成本,为企业创造更多效益。

\section{3 培养管理人员的管理意识}

在房屋建筑施工管理过程中, 管理人员直接影响着工程 项目的管理效果,若管理人员管理意识相对较弱,则会影响工 程管理的整体效率和和质量。因此,施工企业应该加强对管理 人员管理意识的培养, 定期开展相应的培训活动, 提升管理人 员的管理意识。同时, 施工企业还需要积极开展管理文化活 动, 吸引所有施工人员参与到管理培训活动中。另外, 施工管 理人员也要不断提升自身的综合素质, 学习更多相关的管理 知识,培养自身的管理意识。

\section{4 建立严格的监督制度}

在房屋建筑施工过程中, 为了严格执行施工计划, 施工 企业需要制定严格的监督制度，减少施工现场质量问题, 确 保房屋建筑在验收过程中满足相关标准 ${ }^{[3]} 。$ 除此之外, 在实际 的房屋建筑施工中, 相关管理部门需要深入调查、监督、检验 施工全过程, 避免施工过程中出现问题而影响后续施工的有 序开展。

\section{5 结语}

综上所述,在社会发展中,建筑行业之间的市场竞争日益 激烈, 建筑企业需要不断提升自身的综合竞争实力, 加强对施 工全过程的管理。因此,在实际房屋建筑施工过程中, 企业需 要做好施工管理工作,避免出现影响施工质量的问题, 为工程 建设的有效实施提供支持。

\section{参考文献}

[1]陈海林.房屋建筑施工管理中存在的问题及解决对策 [J].河南 建材,2019(4):201-202.

[2]杜靖. 房屋建筑工程施工质量管理中存在的问题及对策 [J].工 程建设与设计,2019(10):210-211.

[3] 马猛然. 房屋建筑施工管理存在的问题及对策 [J]. 居舍,2019 (2): 134 . 